\title{
The Microbiological Effects of Procedures Used in Commercial Practice for Cleaning Mechanical Tenderizing Equipment Used With Beef
}

\author{
M. K. Youssef ${ }^{1,2}$, M. D. Klassen ${ }^{3} \&$ C. O. Gill ${ }^{1}$ \\ ${ }^{1}$ Agriculture \& Agri-Food Canada, Lacombe Research Centre, Lacombe, Canada \\ ${ }^{2}$ Department of Food Hygiene and Control, Cairo University, Giza, Egypt \\ ${ }^{3}$ Canadian Cattlemen's Association, Calgary, Canada \\ Correspondence: C. O. Gill, Agriculture \& Agri-Food Canada, Lacombe Research Centre, 6000 C \& E Trail, \\ Lacombe, Alberta T4L 1W1, Canada. Tel: 1-403-782-8113. E-mail: colin.gill@agr.gc.ca
}

Received: November 28, 2013 Accepted: December 22, 2013 Online Published: January 8, 2014

doi:10.5539/jfr.v3n1p105

URL: http://dx.doi.org/10.5539/jfr.v3n1p105

\begin{abstract}
The microbiological effects of routine cleaning of a common type of blade tenderizing equipment (Ross TC700MC) used with beef at a retail store meat fabrication facility were investigated. Swab samples were obtained from various parts of the equipment before and after its use on each of 5 days, with 17 samples being obtained on each occasion. The median numbers of aerobes recovered before or after use each day were mostly not significantly different $(\mathrm{P}>0.05)$ and $>3.5 \mathrm{log}$ cfu/sample. Enterobacteriaceae and coliforms were recovered after use each day at total numbers of 2.5 - 4.2 and 2.4-3.2 log cfu, respectively; and sometimes before use at total numbers of $1.7-3.9$ and $0.7-2.1 \log$ cfu, respectively. With more careful performance of cleaning procedures by facility staff and storing in a chiller, the numbers of aerobes recovered from the tenderizer before use were $3 \log$ units less than the numbers found on the used equipment, and Enterobacteriaceae and coliforms were not recovered. Studies at a laboratory with a tenderizer used with beef cuts showed that cleaning was equally effective for reducing numbers of aerobic bacteria by $\geq 3 \log$ units when carried out using water of $90{ }^{\circ} \mathrm{C}$ or $55^{\circ} \mathrm{C}$; and that drying of equipment was necessary to prevent growth of Enterobacteriaceae and coliforms on cleaned equipment not stored at chiller temperatures.
\end{abstract}

Keywords: beef, mechanical tenderizing equipment, cleaning, disinfection, drying

\section{Introduction}

In North America, primal cuts of beef used for the preparation of steaks or roasts are often mechanically tenderized by repeated incision with banks of thin blades or needles (Clyma, 2013; George-Evins, Unruh, Marsden, \& Kastner, 2000). Such treatments can carry bacteria from the surface into the previously sterile deep tissue (Johns, Bratcher, Kerth, \& McCaskey, 2011). The bacteria carried into deep tissues may include pathogens, such as Salmonella and Escherichia coli O157:H7, which might survive to pose health risks for consumers if the meat is inadequately cooked. The increase risks of human illness as a result of mechanical tenderizing were initially assessed as very small (US Department of Agriculture, Food Safety and Inspection Service [USDA/FSIS], 2002). However, some recent outbreaks of E. coli O157:H7 illness were associated with consumption of steaks prepared from mechanically tenderized beef (Centers for Disease Control and Prevention [CDC], 2010; Canadian Food Inspection Agency, [CFIA], 2013). This prompted reconsideration of the microbiological risks from tenderized beef, which recently have been assessed as being somewhat greater than previously supposed (Catford et al., 2013; USDA/FSIS, 2012).

Most E. coli $\mathrm{O} 157: \mathrm{H} 7$ on or in mechanically tenderized beef were probably present on the surface of the meat before it was tenderized; or were transferred from a contaminated cut to cuts that immediately followed it through the tenderizing process (Huang \& Sheen, 2011). However, bacteria can and do survive routine cleaning of equipment used for processing beef or other foods (Gibson, Taylor, Hall, \& Holah, 1999; Khamisse, Frimesse, Christieans, Chassaing, \& Carpentier, 2012). Bacteria that persistently survive routine cleaning of equipment can include E. coli or Salmonella, which then can contaminate successive batches of product (Holah, Bird, \& Hall, 2004; van Hoek et al., 2012). Moreover, organisms that persisted in meat processing equipment at a retail outlet or packing plant have been indicated as the likely causes of outbreaks of Salmonella or E. coli O157:H7 illness 
(Lewis, Corriveau, \& Usborne, 2013; Roels et al., 1997). Much of the equipment used for tenderizing beef, at retail stores as well as beef packing or processing plants, is relatively complex. The equipment usually includes one or more banks of closely spaced blades or needles that are repeatedly driven through product carried beneath them on a conveyor belt. Some parts of such equipment may be difficult to access for cleaning. Tenderizing equipment may then sometimes be a persistent source for $E$. coli $\mathrm{O} 157: \mathrm{H} 7$ contamination of beef.

Outbreaks of E. coli O157:H7 illness associated with consumption of mechanically tenderized beef have not been reported frequently (Laine et al., 2005); and the role of tenderizing processes in the reported outbreaks are uncertain. For example, the two most recent outbreaks each involved both tenderized and not tenderized beef from the same source, with both type of product being recalled because of contamination with E. coli $\mathrm{O} 157: \mathrm{H} 7$ (CDC, 2010; Lewis et al., 2013). Assessment of the extent to which tenderizing of contaminated beef might increase the risk to consumers seemingly requires consideration of the possible persistence of E. coli $\mathrm{O} 157: \mathrm{H} 7 \mathrm{in}$ tenderizing equipment. Information on that matter is lacking. Therefore, the microbiological effects of cleaning procedures currently used in commercial practice for cleaning tenderizing equipment used with beef were investigated.

\section{Material and Methods}

\subsection{Tenderizing Equipment}

The tenderizers from which samples were obtained were manufactured by Ross Industries Inc. (Midland, VA, USA). Tenderizers of this type are widely used throughout the North American beef industry, at meat packing and processing plants and at meat fabrication facilities of retail stores.

With the Ross Industries type of tenderizer, the meat to be tenderized is placed on a conveyor belt which advances by $18 \mathrm{~mm}$ or $36 \mathrm{~mm}$ increments to carry the meat below a blade head or two blade heads in series, respectively. Each blade head carries a bank of blades that descend after each advance of the belt to penetrate the meat. The belt is comprised of stainless steel rods that run the full width of the belt and are linked at the belt edges. Meat to be tenderized is placed on the upper surface of the looped belt. Panels of stainless steel under the upper part of the looped belt support the belt and product on it when the meat is incised. A top plate covers each blade head. Each blade head is composed of a magnetic holder for the blades, which are arranged in 7 rows of 32 blades each; a plastic blade guide plate with slots for the blades to pass through it; and guide rods at the sides of the blade holder that pass through the guide plate. The stainless steel blades are $3 \times 1 \mathrm{~mm}$ in cross section. When the blade head descends, the guide plate contacts the meat while the blades are driven into it. The magnetic holder allows individual blades to retract through it if they encounter bone or another solid material. The equipment is designed to allow rapid release of the conveyor belt and blade head so that they can be removed for cleaning.

The tenderizer used at the retail store meat processing facility involved in the study was a Ross Industries model TC700 MC, which has a single blade head. The tenderizer used for laboratory studies was a Ross Industries model TC700 W, which has two blade heads.

\subsection{Use and Cleaning of the Tenderizer at a Retail Store}

At the retail store involved in the study the tenderizer is usually operated for about $1 \mathrm{~h}$ each day, to tenderized beef at the beginning of the working day. The product that is tenderized is vacuum packaged sub-primal cuts from Canadian packing plants. The tenderizer is cleaned along with other equipment, and the facility itself, after cut fabrication is completed for the day.

The store's Standard Operating Procedure (SOP) for cleaning the tenderizer after use is as follows. The top plate covering the blade head and its support structures, the blade head, the belt and the stainless steel panels beneath the upper part of the looped belt are removed from the equipment for cleaning. A basin of suitable size is filled with a solution of foaming chlorinated sanitizer/cleaner (FS Process Cleaner; Zep, Inc., Edmonton, Alberta, Canada), prepared according to the manufacturer's instructions. The blade head is disassembled and the top plate and blade head components are soaked in the solution for up to $5 \mathrm{~min}$. Then, those parts and all other parts that are removed, except the blade holder, are washed in the solution. During washing the parts are scrubbed as is necessary to remove detritus and fat. After washing the parts are rinsed in running water, sprayed with a solution of a quaternary ammonium (quat) sanitizer (ZEP FS Amine Z, Zep Inc.) prepared according to the manufacturer's instructions, and left to dry overnight. The blade holder is washed using a high pressure spray, dried using a hot air gun, and sprayed with quat sanitizer solution and then with mineral oil. Hot water for washing and rinsing is provided at a temperature of $90{ }^{\circ} \mathrm{C}$. The equipment with parts removed is sprayed with a solution of the foaming chlorinated sanitizer/cleaner. After standing for $>10 \mathrm{~min}$, the cleaner is rinsed from the 
equipment with hot water, then sprayed with the quat sanitizer solution. The equipment is assembled the next day.

\subsection{Collection of Samples at the Retail Store}

Samples were collected by swabbing parts of the tenderizer with sterile synthetic sponges (Speci-sponge, VWR, Canlab, Edmonton, Alberta, Canada) that had been moistened with $10 \mathrm{ml}$ of $0.1 \%$ (w/v) peptone water (Difco, Becton Dickinson, Sparks, MD, USA). In addition, moistened sponges were sent through the operating equipment.

On each of 5 days during a 3 week period, samples were collected from the tenderizer before it was used and again when use of the tenderizer had ended. During this time the equipment was cleaned by staff of the facility in accordance with established practices. The staff considered that their established practices conformed adequately with the requirements of the SOP. The cleaned equipment was held overnight in the processing facility, without refrigeration. The staff were informed of the results of the microbiological sampling. In response, the staff modified their established practices to carefully adhere to all requirements of the SOP. In addition, the cleaned equipment was held overnight in the meat storage chiller. After the improved cleaning practices had been adopted, on two occasions, samples were collected from the tenderizer after it was cleaned one day and before it was used on the following day.

At each time of sampling before improvement of the cleaning practices, 5 sponges were sent through the operating equipment, 5 bars of the belt were each swabbed with a sponge, 5 sponges were used to swab the blade head support structures, and the bottoms of the blade guide plate and the blade holder were each swabbed with a single sponge. After improvement of cleaning practices the assembled tenderizer was sampled in the same manner before it was used. However, the equipment was necessarily disassembled for cleaning and was not reassembled until the next day. Therefore, sponges could not be passed through the operating tenderizer immediately after it was cleaned. Consequently, only swab samples were collected from the cleaned, disassembled tenderizer. Each sponge used for swabbing or passed through the tenderizer was placed in a separate stomacher bag and was held on ice until it was processed within $3 \mathrm{~h}$ of being collected.

\subsection{Operation and Cleaning of the Tenderizer at a Laboratory and Collection of Samples From the Tenderizer}

At the laboratory on each of 4 days the tenderizer was operated to tenderize 3 top butt primal beef cuts that had been stored at $-1.5^{\circ} \mathrm{C}$ for between 12 and 14 weeks. The cuts were held for this time to ensure the spoilage microflora were at maximum numbers. Each cut was passed through the tenderizer 10 times, to ensure the equipment would be extensively contaminated with bacteria from the flora on cuts. After use of the tenderizer the equipment was sampled as was the tenderizer at the retail store. A separate swab sample was obtained from the blade holder and blade guide plate of each blade head.

After sampling of the used tenderizer it was cleaned according to the SOP for cleaning the tenderizer at the retail store, with use of the cleaner and sanitizer used at the facility. On two days cleaning was carried out using warm water provided at $55^{\circ} \mathrm{C}$. On two other days cleaning was carried out using hot water provided at $90{ }^{\circ} \mathrm{C}$. After cleaning, swab samples were collected from the equipment as before. As the tenderizer was disassembled for cleaning, and was not assembled until the next day to accord with practice at the retail store, samples could not be collected by passing sponges through the operating tenderizer immediately after cleaning.

On one day after the tenderizer had been cleaned using warm water, and one day after it had been cleaned using hot water, the disassembled tenderizer was left uncovered overnight to allow drying. On the two other days the cleaned equipment was enveloped in previously unused plastic sheets, to inhibit drying of the equipment. Each day after the cleaned equipment had been held overnight, the tenderizer was reassembled and sampled as before, by swabbing and by passing sponges through the operating tenderizer. All samples collected at the laboratory were held on ice and processed within $2 \mathrm{~h}$ of being collected.

\subsection{Processing of Samples}

A further $5 \mathrm{ml}$ of peptone water was added to the sponge in each stomacher bag, then the sponge and diluent were pummelled for $2 \mathrm{~min}$ in a stomacher operating at low speed. A $1 \mathrm{ml}$ portion of each stomacher fluid was used to prepare ten-fold serial dilutions in peptone water, to $10^{-4}$ with samples from the retail store tenderizer and to $10^{-7}$ with samples from the laboratory tenderizer. Then, $1 \mathrm{ml}$ of the undiluted fluid and each dilution were each inoculated to a Petrifilm ${ }^{\circledR}$ aerobic count plate (3M Corps., St. Paul, MN, USA), $1 \mathrm{ml}$ of undiluted fluid and each dilution to $10^{-2}$ were each inoculated to a Petrifilm ${ }^{\circledR}$ Enterobacteriaceae plate (3M Corp.), and $5 \mathrm{ml}$ of undiluted fluid and each dilution to $10^{-2}$ were each inoculated to a Petrifilm ${ }^{\circledR}$ high sensitivity coliform plate (3M Corp.). Aerobic count plates were incubated at $25{ }^{\circ} \mathrm{C}$ for $48 \mathrm{~h}$. Enterobacteriaceae plates and high sensitivity coliform 
plates were incubated at $35^{\circ} \mathrm{C}$ for $24 \mathrm{~h}$. Colonies were counted on plates preferably bearing between 20 and 100 colonies. The levels of detection were $15 \mathrm{cfu} / \mathrm{sample}$ for aerobes and Enterobacteriaceae, and $3 \mathrm{cfu} / \mathrm{sample}$ for coliforms.

\subsection{Analysis of Data}

Counts of the same type obtained for samples collected from a tenderizer at the same sampling time were regarded as a set. When sets were of the same size, statistics for each full set were calculated and compared. When sets were of unequal size, because groups of samples had been collected from both assembled and disassembled tenderizers, statistics for subsets of counts obtained for swab samples were compared. When appropriate, statistics for subsets of counts obtained for sponges that had passed through an operating tenderizer were compared.

All aerobic counts were transformed to log values. Values for the mean $(\bar{x})$, standard deviation (s) and median (m) were calculated for each set or subset of log counts, using Microsoft Excel, version 6 (Microsoft Corp., Redmond, WA, USA). A Shapiro-Wilk test for normal distribution was applied to each set or subset of counts using SAS version 6:12 (SAS Institute, Cary, NC, USA). Mean values for groups of sets or subsets that included no more than one value that was not normally distributed $(\mathrm{P}<0.05)$ were separated using the Tukey option of the general linear model procedure in SAS, with $\mathrm{P}<0.05$. Median values for groups of sets or subsets that included two or more sets or subsets that were not normally distributed $(\mathrm{P}<0.05)$ were separated pairwise by application of a Kruskal-Wallis test using the NPAR1WAY procedure in SAS, with $\mathrm{P}<0.05$.

For each set of counts of each type, a value for the log of the total number of bacteria recovered $(\mathrm{N})$ was calculated by summing the counts and obtaining the log of the sum.

\section{Results}

Four of 10 sets of $\log$ values for aerobic counts obtained for samples from the tenderizer at the retail store before or after its use were not normally distributed $(\mathrm{P}<0.05$; Table 1$)$. The median values for 9 of those sets were $>3.5 \log$ cfu/sample and those values were not significantly different $(\mathrm{P}>0.05)$.

Table 1. Statistics for the numbers of aerobes recovered from groups of 17 samples from mechanical tenderizing equipment at a retail store on each of 5 days, with samples being collected each day from the equipment before it was used and after it had been used for tenderizing beef primal cuts

\begin{tabular}{|c|c|c|c|c|c|}
\hline \multirow{2}{*}{ Day } & \multirow{2}{*}{ Time of sampling } & \multicolumn{4}{|c|}{ Statistics } \\
\hline & & $\bar{x}^{\mathrm{a}}$ & $s^{b}$ & $\mathrm{~m}^{\mathrm{c}}$ & $\mathrm{N}^{\mathrm{d}}$ \\
\hline \multirow[t]{2}{*}{1} & Before use & 2.80 & 0.67 & $2.61 \mathrm{~A}$ & 4.42 \\
\hline & After use & 4.30 & 0.97 & $4.56 \mathrm{~B}$ & 6.05 \\
\hline \multirow[t]{2}{*}{2} & Before use & $3.33^{\mathrm{e}}$ & 1.14 & $3.88 \mathrm{AB}$ & 5.24 \\
\hline & After use & $4.17^{\mathrm{e}}$ & 0.67 & $4.14 \mathrm{~B}$ & 6.24 \\
\hline \multirow[t]{2}{*}{3} & Before use & $4.11^{\mathrm{e}}$ & 0.69 & $3.83 \mathrm{~B}$ & 5.96 \\
\hline & After use & 3.51 & 0.82 & $3.61 \mathrm{AB}$ & 5.45 \\
\hline \multirow[t]{2}{*}{4} & Before use & 4.01 & 0.67 & $4.06 \mathrm{~B}$ & 5.53 \\
\hline & After use & 3.88 & 0.81 & 3.64B & 6.19 \\
\hline \multirow[t]{2}{*}{5} & Before use & $4.28^{\mathrm{e}}$ & 1.65 & $4.59 \mathrm{~B}$ & 6.83 \\
\hline & After use & 3.68 & 0.73 & $3.64 \mathrm{~B}$ & 5.63 \\
\hline
\end{tabular}

${ }^{\mathrm{a}}$ Mean of the $\log$ values.

${ }^{\mathrm{b}}$ Standard deviation of the set of $\log$ values.

${ }^{\mathrm{c}}$ Median log value.

${ }^{\mathrm{d}} \mathrm{Log}$ of the total number recovered from 17 samples.

${ }^{\mathrm{e}}$ The set of $\log$ values is not normally distributed $(\mathrm{P}<0.05)$.

Median values with the same letter are not significantly different $(\mathrm{P}>0.05)$. 
Enterobacteriaceae and coliforms were recovered from all groups of samples from the tenderizer at the retail store after it was used (Table 2). Enterobacteriaceae were recovered from three and coliforms from two of the groups of samples from the tenderizer before it was used. For groups of samples obtained on two days, the log total numbers of Enterobacteriaceae and coliforms recovered from the tenderizer before it was used were $<1 \log$ unit less than the numbers of the same organisms recovered from the tenderizer after it was used.

Table 2. Statistics for the numbers of Enterobacteriaceae and coliforms recovered from groups of 17 samples from mechanical tenderizing equipment at a retail store on each of 5 days, with samples being collected each day from the equipment before it was used and after it had been used for tenderizing beef primal cuts

\begin{tabular}{|c|c|c|c|c|c|}
\hline \multirow{3}{*}{ Day } & \multirow{3}{*}{ Time of Sampling } & \multicolumn{4}{|c|}{ Statistics } \\
\hline & & \multicolumn{2}{|c|}{ Enterobacteriaceae } & \multicolumn{2}{|c|}{ Coliforms } \\
\hline & & $\mathrm{no}^{\mathrm{a}}$ & $\mathrm{N}^{\mathrm{b}}$ & no & $\mathrm{N}$ \\
\hline \multirow[t]{2}{*}{1} & Before use & 17 & $\mathrm{ND}^{\mathrm{c}}$ & 17 & ND \\
\hline & After use & 6 & 3.51 & 4 & 3.19 \\
\hline \multirow[t]{2}{*}{2} & Before use & 17 & ND & 17 & ND \\
\hline & After use & 2 & 4.16 & 3 & 3.28 \\
\hline \multirow[t]{2}{*}{3} & Before use & 14 & 2.21 & 17 & ND \\
\hline & After use & 8 & 2.50 & 9 & 2.45 \\
\hline \multirow[t]{2}{*}{4} & Before use & 14 & 1.65 & 15 & 0.70 \\
\hline & After use & 5 & 3.35 & 7 & 2.48 \\
\hline \multirow[t]{2}{*}{5} & Before use & 11 & 3.93 & 13 & 2.07 \\
\hline & After use & 11 & 3.17 & 9 & 2.35 \\
\hline
\end{tabular}

${ }^{a}$ Number of samples from which Enterobacteriaceae or coliforms were not recovered.

${ }^{\mathrm{b}} \mathrm{Log}$ of the total number recovered from 17 samples.

${ }^{\mathrm{c}}$ None detected at the level of $15 \mathrm{cfu} / \mathrm{sample}$ or $3 \mathrm{cfu} / \mathrm{samples}$ for Enterobacteriaceae and coliforms, respectively.

Three of the four sets of log values for aerobic counts obtained for swab samples from the tenderizer at the retail store cleaned with careful adherence to the SOP for cleaning, before or after holding in the meat storage chiller overnight, were not normally distributed $(\mathrm{P}<0.05)$. The median values for the four sets were all $<2.0 \log$ cfu/sample, and those values were not significantly different ( $P>0.05$; Table 3 ). No Enterobacteriaceae or coliforms were recovered from any of the four groups or subgroups of samples. The median numbers of aerobes recovered from the groups of 5 sponges passed through the tenderizer before it was used on two days were each 1.0 $\log \mathrm{cfu} / \mathrm{sample}$, and those values were not significantly different $(\mathrm{P}>0.05)$. No Enterobacteriaceae or coliforms were recovered from those sponges.

Table 3. Statistics for the numbers of aerobes recovered from groups of 12 samples from mechanical tenderizing equipment at a retail store on each of 2 days, with samples being collected each day from equipment after it was cleaned and after standing overnight

\begin{tabular}{|c|c|c|c|c|c|}
\hline \multirow{2}{*}{ Day } & \multirow{2}{*}{ Time of sampling } & \multicolumn{4}{|c|}{ Statistics } \\
\hline & & $\bar{x}^{\mathrm{a}}$ & $\mathrm{s}^{\mathrm{b}}$ & $\mathrm{m}^{\mathrm{c}}$ & $\mathrm{N}^{\mathrm{d}}$ \\
\hline \multirow[t]{2}{*}{1} & After cleaning & 1.83 & 0.65 & $1.72 \mathrm{~A}$ & 3.41 \\
\hline & After standing & $1.54^{\mathrm{e}}$ & 0.70 & $1.18 \mathrm{~A}$ & 3.48 \\
\hline \multirow[t]{2}{*}{2} & After cleaning & $1.29^{\mathrm{e}}$ & 0.28 & $1.18 \mathrm{~A}$ & 2.45 \\
\hline & After standing & $1.68^{\mathrm{e}}$ & 0.72 & $1.41 \mathrm{~A}$ & 3.35 \\
\hline
\end{tabular}

\footnotetext{
${ }^{a}$ Mean of the log values.

${ }^{\mathrm{b}}$ Standard deviation of the set of log values.
} 
c Median log value.

${ }^{\mathrm{d}} \mathrm{Log}$ of the total number recovered from 17 samples.

e The set of $\log$ values is not normally distributed $(\mathrm{P}<0.05)$.

Median values with the same letter are not significantly different $(\mathrm{P}>0.05)$.

The four sets of log values for aerobic counts obtained from swab samples from the tenderizer at the laboratory after it had been used for tenderizing beef were not normally distributed $(\mathrm{P}<0.05$; Table 4$)$. The median values for the sets were all $>7.5 \log \mathrm{cfu} /$ sample, and those values were not significantly different $(\mathrm{P}>0.05)$. The mean values for the sets were less than the corresponding median values. Seven of the 8 sets of log values for aerobic counts obtained for swab samples from the tenderizer after it was cleaned or after standing overnight were normally distributed $(\mathrm{P}>0.05)$. Mean values for 3 of the 4 sets of aerobic counts obtained for swab samples from the tenderizer after it was cleaned with warm or hot water were $>3.5 \log$ cfu/sample and were not significantly different $(\mathrm{P}>0.05)$. The mean value for the other set of those counts was $>2.5 \log \mathrm{cfu} / \mathrm{sample}$ and was significantly different $(\mathrm{P}<0.05)$ than the other three mean values. The mean values for each pair of sets of aerobic counts obtained from swab samples after cleaning and on the following day after overnight standing were not significantly different $(\mathrm{P}>0.05)$. The differences between mean values for sets of counts for samples obtained before cleaning or after cleaning and standing ranged from 3.1 to $5.0 \log$ units.

Table 4. Statistics for the numbers of aerobes recovered from groups of 14 samples from mechanical tenderizing equipment used for tenderizing beef primal cuts, before the equipment was cleaned, after cleaning using hot $\left(90{ }^{\circ} \mathrm{C}\right)$ or warm $\left(55^{\circ} \mathrm{C}\right)$ water, and after standing overnight with or without drying during standing

\begin{tabular}{|c|c|c|c|c|}
\hline \multirow{2}{*}{ Equipment condition } & \multicolumn{4}{|l|}{ Statistics } \\
\hline & $\bar{x}^{\mathrm{a}}$ & $\mathrm{s}^{\mathrm{b}}$ & $\mathrm{m}^{\mathrm{c}}$ & $\mathrm{N}^{\mathrm{d}}$ \\
\hline Before cleaning & $7.35^{\mathrm{e}}$ & 1.09 & $7.75 \mathrm{~A}$ & 8.89 \\
\hline After cleaning with warm water & $3.94 \mathrm{~A}$ & 0.97 & 3.68 & 5.20 \\
\hline After standing without drying & $4.25 \mathrm{~A}$ & 0.74 & 4.26 & 5.95 \\
\hline Before cleaning & $7.33^{\mathrm{e}}$ & 1.06 & $7.65 \mathrm{~A}$ & 8.89 \\
\hline After cleaning with warm water & $3.49 \mathrm{AB}$ & 0.61 & 3.39 & 5.06 \\
\hline After standing with drying & 2.99BCD & 0.47 & 3.08 & 4.32 \\
\hline Before cleaning & $7.36^{\mathrm{e}}$ & 1.47 & $7.96 \mathrm{~A}$ & 9.07 \\
\hline After cleaning with hot water & $3.53 \mathrm{AB}$ & 0.69 & 3.42 & 4.54 \\
\hline After standing without drying & 3.47ABC & 0.54 & 3.55 & 4.93 \\
\hline Before cleaning & $7.33^{\mathrm{e}}$ & 0.47 & $7.54 \mathrm{~A}$ & 8.65 \\
\hline After cleaning with hot water & $2.68^{\mathrm{e}} \mathrm{CD}$ & 0.89 & 2.33 & 4.74 \\
\hline After standing with drying & $2.35 \mathrm{D}$ & 0.63 & 2.22 & 3.90 \\
\hline
\end{tabular}

${ }^{a}$ Mean of the log values.

${ }^{\mathrm{b}}$ Standard deviation of the set of $\log$ values.

${ }^{\mathrm{c}}$ Median log value.

${ }^{\mathrm{d}} \mathrm{Log}$ of the total number recovered from 17 samples.

${ }^{\mathrm{e}}$ The set of $\log$ values is not normally distributed $(\mathrm{P}<0.05)$.

Median values with the same letter are not significantly different $(\mathrm{P}>0.05)$.

Mean values with the same letter are not significantly different $(P>0.05)$.

Enterobacteriaceae were recovered from all, and coliforms were recovered from most swab samples from the tenderizer at the laboratory after it was used; at log total numbers $>3.0$ and $>2.5 \log \mathrm{cfu} / 14$ samples, respectively (Table 5). No Enterobacteriaceae were and a single coliform only was recovered from the tenderizer after cleaning with warm or hot water. No Enterobacteriaceae or coliforms were recovered from the tenderizer when it was 
allowed to dry after cleaning, but small numbers of those organisms were recovered from a few samples when drying after cleaning was prevented.

All sets of log values for aerobic counts obtained for sponges passed through the tenderizer at the laboratory before it was cleaned or after it was cleaned and allowed to stand overnight were normally distributed ( $>0.05$; Table 6$)$. Mean values for three of the four sets of aerobic counts obtained for sponges passed through the tenderizer before it was cleaned were not significantly different $(\mathrm{P}>0.05)$. Mean values for two of the four sets of aerobic counts obtained from sponges after the tenderizer was cleaned and allowed to stand overnight were significantly different $(\mathrm{P}<0.05)$ from one another and from the mean values for the other two sets. The differences between mean values for sets of counts obtained from sponges passed through the tenderizer before cleaning or after cleaning and standing ranged from 2.6 to 3.8 log units.

Table 5. Statistics for the numbers of Enterobacteriaceae and coliforms recovered from groups of 14 samples from mechanical tenderizing equipment used for tenderizing beef primal cuts, before the equipment was cleaned, after cleaning using hot $\left(90^{\circ} \mathrm{C}\right)$ or warm $\left(55^{\circ} \mathrm{C}\right)$ water, and after standing overnight with or without drying during standing

\begin{tabular}{|c|c|c|c|c|}
\hline \multirow{3}{*}{ Equipment condition } & \multicolumn{4}{|c|}{ Statistics } \\
\hline & \multicolumn{2}{|c|}{ Enterobacteriaceae } & \multicolumn{2}{|c|}{ Coliforms } \\
\hline & $\mathrm{no}^{\mathrm{a}}$ & $\mathrm{N}^{\mathrm{b}}$ & no & $\mathrm{N}$ \\
\hline Before cleaning & 0 & 3.40 & 2 & 3.31 \\
\hline After cleaning with warm water & 14 & $\mathrm{ND}^{\mathrm{c}}$ & 13 & 0.00 \\
\hline After standing without drying & 11 & 1.68 & 13 & 0.51 \\
\hline Before cleaning & 0 & 3.56 & 0 & 2.90 \\
\hline After cleaning with warm water & 14 & ND & 14 & ND \\
\hline After standing with drying & 14 & ND & 14 & ND \\
\hline Before cleaning & 0 & 3.93 & 0 & 2.77 \\
\hline After cleaning with hot water & 14 & ND & 14 & ND \\
\hline After standing without drying & 13 & 1.20 & 12 & 0.78 \\
\hline Before cleaning & 0 & 4.34 & 1 & 3.10 \\
\hline After cleaning with hot water & 14 & ND & 14 & ND \\
\hline After standing with drying & 14 & ND & 14 & ND \\
\hline
\end{tabular}

${ }^{a}$ Number of samples from which Enterobacteriaceae or coliforms were not recovered.

${ }^{\mathrm{b}}$ Log of the total number recovered from 17 samples.

${ }^{\mathrm{c}}$ None detected at the level of $15 \mathrm{cfu} / \mathrm{sample}$ or $3 \mathrm{cfu} / \mathrm{sample}$ for Enterobacteriaceae and coliforms, respectively. 
Table 6. Statistics for the numbers of aerobes recovered from groups of 5 sponges that were passed through mechanically tenderizing equipment used for tenderizing beef primal cuts while the equipment was operating, before the equipment was cleaned or after the equipment had been cleaned using hot $\left(90{ }^{\circ} \mathrm{C}\right)$ or warm $\left(55^{\circ} \mathrm{C}\right)$ water and the equipment had stood overnight with or without drying during standing

\begin{tabular}{|c|c|c|c|c|}
\hline \multirow{2}{*}{ Equipment condition } & \multicolumn{4}{|l|}{ Statistics } \\
\hline & $\bar{x}^{\mathrm{a}}$ & $\mathrm{s}^{\mathrm{b}}$ & $\mathrm{m}^{\mathrm{c}}$ & $\mathrm{N}^{\mathrm{d}}$ \\
\hline Before cleaning & $7.00 \mathrm{~A}$ & 0.13 & 6.97 & 7.72 \\
\hline Cleaned with warm water, not dried & $4.34 \mathrm{C}$ & 0.22 & 4.35 & 5.09 \\
\hline Before cleaning & $6.86 \mathrm{AB}$ & 0.16 & 6.89 & 7.59 \\
\hline Cleaned with warm water, dried & $3.73 \mathrm{D}$ & 0.44 & 3.83 & 4.61 \\
\hline Before cleaning & $6.80 \mathrm{AB}$ & 0.40 & 6.70 & 7.69 \\
\hline Cleaned with hot water, not dried & $3.28 \mathrm{D}$ & 0.06 & 3.27 & 3.99 \\
\hline Before cleaning & $6.38 \mathrm{~B}$ & 0.23 & 6.41 & 7.12 \\
\hline Cleaned with hot water, dried & $2.55 \mathrm{E}$ & 0.37 & 2.48 & 3.39 \\
\hline
\end{tabular}

${ }^{a}$ Mean of the log values.

${ }^{\mathrm{b}}$ Standard deviation of the set of log values.

${ }^{\mathrm{c}}$ Median log value.

${ }^{\mathrm{d}} \mathrm{Log}$ of the total number recovered from 5 samples.

All sets of log values are normally distributed $(\mathrm{P}>0.05)$.

Mean values with the same letter are not significantly different.

Enterobacteriaceae were recovered from all sponges that were passed through the tenderizer at the laboratory before it was cleaned; and coliforms were recovered from all but one of those sponges (Table 7). No Enterobacteriaceae or coliforms were recovered from sponges passed through the tenderizer after it had been cleaned and allowed to stand overnight.

Table 7. Statistics for the numbers of Enterobacteriaceae and coliforms recovered from groups of 5 sponges that were passed through mechanically tenderizing equipment used for tenderizing beef primal cuts while the equipment was operating, before the equipment was cleaned or after the equipment had been cleaned using hot $\left(90{ }^{\circ} \mathrm{C}\right)$ or warm $\left(55^{\circ} \mathrm{C}\right)$ water and the equipment had stood overnight with or without drying during standing

\begin{tabular}{|c|c|c|c|c|}
\hline \multirow{3}{*}{ Equipment condition } & \multicolumn{4}{|c|}{ Statistics } \\
\hline & \multicolumn{2}{|c|}{ Enterobacteriaceae } & \multicolumn{2}{|c|}{ Coliforms } \\
\hline & $\mathrm{no}^{\mathrm{a}}$ & $\mathrm{N}^{\mathrm{b}}$ & no & $\mathrm{N}$ \\
\hline Before cleaning & 0 & 2.80 & 0 & 2.07 \\
\hline Cleaned with warm water, not dried & 5 & ND & 5 & ND \\
\hline Before cleaning & 0 & 2.28 & 0 & 1.78 \\
\hline Cleaned with warm water, dried & 5 & ND & 5 & ND \\
\hline Before cleaning & 0 & 2.35 & 0 & 1.28 \\
\hline Cleaned with hot water, not dried & 5 & ND & 5 & ND \\
\hline Before cleaning & 0 & 3.08 & 1 & 1.87 \\
\hline Cleaned with hot water, dried & 5 & ND & 5 & ND \\
\hline
\end{tabular}

${ }^{a}$ Number of samples from which Enterobacteriaceae or coliforms were not recovered.

${ }^{\mathrm{b}} \log$ of the total number recovered from 5 sponges. 


\section{Discussion}

The chlorinated detergent and quat sanitizer used with the tenderizers are products of types that are widely used for cleaning and sanitizing meat processing equipment (Holah, Taylor, Dawson, \& Hall, 2002). Even so, routine cleaning of the tenderizer at the retail store and, possibly, management of the cleaned equipment was evidently not consistently effective for controlling the numbers of bacteria on it. The bacteria recovered from the retail store tenderizer, after as well as before cleaning, would mostly be derived from the vacuum packaged product with which it was used. The bacteria surviving on the cleaned equipment would then very largely be psychrotrophic lactic acid bacteria that are not hazardous for consumers (Corry, 2007). However, the presence of Enterobacteriaceae and coliforms on cleaned equipment indicates the possibility of survival and growth on the equipment of pathogenic members of those groups, such as E. coli O157:H7 and Salmonella (Pandey, Joshi, Nigam, \& Soccol, 1999), that may be acquired from beef.

Routine cleaning of meat processing equipment at some commercial facilities has been reported to have little effect on levels of bacterial contamination (Ho, Huang, \& Chen, 2004; Khamisse et al., 2012). Such situations probably arise because there are two objectives of equipment cleaning. These are removal of food particles, soils and residues to obtain visibly clean equipment, and reducing numbers of bacteria to acceptable levels (Keener, 2005). Sampling of cleaned equipment for microbiological testing is a routine practice at large meat processing plants and is carried out occasionally at many small facilities. However, the value of such testing for directing cleaning practices will be very limited if the criteria for acceptable cleaning are only general guidelines rather than criteria specific for the equipment and product in question. In such circumstances the effects of cleaning will be judged largely by the visible cleanliness of cleaned equipment. Procedures required for control of bacterial contamination, but which have no effect on visible cleanliness, may then be discounted. Thus, at the facility involved in this study the routine cleaning practices gave uncertain control of bacterial contaminants on the visibly clean tenderizing equipment with the maximum reduction in the numbers of aerobes being less than two log units. The adoption of practices aimed at improved control over microbiological contamination resulted in aerobic counts being consistently reduced by three of more log units, and Enterobacteriaceae and coliforms being reduced to undetectable levels.

The extent to which staff at the commercial facility could vary the cleaning process was very limited. Therefore, work was carried out with the laboratory tenderizer to identify the effects of wash water temperature and conditions for holding equipment after cleaning on the microbiological condition of tenderizing equipment. To obtain the maximum, natural contamination of the tenderizer it was used to tenderize vacuum packaged beef that had been stored for times sufficient for the spoilage flora to attain maximum numbers (A. O. Gill, \& C. O. Gill, 2010). In contrast, most beef tenderized at retail stores will have been stored for three weeks or less and will carry spoilage flora of numbers well below the maximum (Gill et al., 2002; Badoni, Rajagopal, Aalhus, Klassen, \& Gill, 2012). The differences of 3 or $4 \log$ units in the mean numbers of aerobes recovered from the tenderizer at the retail store and the tenderizer at the laboratory were then expected.

The tenderizer at the retail store was washed with water delivered at $90{ }^{\circ} \mathrm{C}$. Washing meat processing equipment with water at such high temperatures is not considered a desirable practice, because high temperatures may alter the detergent properties of cleaning compounds and cause refractory films of denatured protein to form on equipment surfaces (Keener, 2005). It was, however, conceivable that the high temperatures contributed to inactivation of bacteria on the equipment. In the event, the findings with the laboratory tenderizer indicated that washing with warm or hot water was equally effective for controlling bacteria.

At the retail store, after the tenderizer was cleaned using the improved procedure it was held overnight at chiller temperatures. This would greatly restrict any growth of surviving bacteria. Holding cleaned tenderizing equipment under chiller conditions may well not be an option at all meat processing facilities. Growth, and possibly survival of bacteria on cleaned equipment might then be prevented by drying the equipment (Kusumaningrum, Riboldi, Hazeleger, \& Beumer, 2003; Møretrø, Heir, Ho, Habimana, Abdelgani, \& Langsrud, 2010). The work with the tenderizer at the laboratory showed that when the cleaned equipment was held at non-refrigerated temperatures and drying was prevented, Enterobacteriaceae and coliforms that were undetectable on the cleaned equipment could grow to detectable numbers. This indicates that drying of cleaned tenderizing equipment, or holding it under refrigeration, should be part of the procedure for ensuring the equipment cannot become a source of hazardous contaminants for beef.

Control of the microbiological contamination of beef at North American packing plants has apparently greatly improved in recent years (Youssef, Badoni, Yang, \& Gill, 2013). This probably accounts for the recent large reductions in the incidences of E. coli O157 illness in the USA and Canada (CDC, 2012; Public Health Agency of 
Canada, PHAC, 2013). Even so, contamination of batches of beef with E. coli O157 evidently can still occur. The findings of the study indicate that in some circumstances visibly clean but inadequately sanitized tenderizing equipment might transmit enteric pathogens between batches of beef processed on different days. This would be precluded by the adoption and maintenance of appropriate, validated procedures for cleaning, drying and storing the equipment. Tenderizing of beef is carried on at many small facilities where microbiological monitoring of the adequacy of equipment cleaning is infrequent or not an option. Reliance must then be placed on SOPs for cleaning the equipment. An SOP for a small facility obviously should describe the cleaning process in detail, with identification of cleaning equipment, water temperatures, cleaning times, etc. However, the findings of this study indicate that, in addition, the objective of removing and controlling bacterial contaminants as well as visible contamination should be explained. The explanation of cleaning objectives would allow cleaning staff to better appreciate the need for strict adherence to the SOP. The risk of persistent hazardous bacterial contamination of tenderizing equipment would seem to be small, but appropriate cleaning and drying of tenderizing equipment is necessary if such risks are to be negligible.

\section{Acknowledgements}

The provision by the management and staff of the retail store meat processing facility of information about facility practices and facilitation of sample collection is greatly appreciated. The study was carried out as part of the E. coli O157 Research and Education Strategy of the Canadian Cattlemen's Association. Funding for the study was provided by the Alberta Livestock and Meat Agency from the Agency's Strategic Initiatives Fund. The tenderizing equipment used at the laboratory was kindly loaned for the study by Ross Industries Inc.

\section{References}

Badoni, M., Rajagopal, S., Aalhus, J. L., Klassen, M. D., \& Gill, C. O. (2012). The microbiological condition of beef steaks offered for retail sale in Canada. Journal of Food Research, 1, 124-133. http://dx.doi.org/10.5539/jfr.v1n4p124

Canadian Food Inspection Agency [CFIA]. (2013). Policy on the control of E. coli O157:H7/NM contamination in raw beef products: Section 5.7.1. Labeling requirements for mechanically tenderized beef. Retrieved from http://www.inspection.gc.ca/food/meat-and-poultry-products/manual-of-procedures/chapter-4/annex-o/eng/ $1370616273137 / 1370616333827 \# \mathrm{a} 5$

Catford, A., Lavoie, M. C., Smith, B., Buenaventura, E., Couture, H., Fazil, A., \& Farber, J. M. (2013). Findings of the health risk assessment of Escherichia coli O157 in mechanically tenderized beef products in Canada. International Food Risk Analysis Journal, 3, 1-12. http://dx.doi.org/10.5772/76713

CDC. (2012). Trends in foodborne illness in the United States, 2012. Retrieved from http://www.cdc.gov/features/dsfoodnet2012/figure2.html

Centers for Disease Control and Prevention [CDC]. (2010). Multistate outbreak of E. coli O157:H7 infections associated with beef from National Steak and Poultry. Centers for Disease Control, Final Update, January 6, 2010. http://www.cdc.gov/ecoli/2010/

Clyma, K. (2013). Washing away risk. Meat and Poultry, April 2013, 38-41 Retrieved from http://www.meatpoultry.com/articles/news_home/Food_Safety/2013/04/Washing_away_risk.aspx?ID=07B 9E217E75-794D-479A-BEA1-559E89D4C̄60C\%7D\&cck=1

Corry, J. E. L. (2007). Spoilage organisms of red meat and poultry. In G. C. Mead (Ed.), Microbiological Analysis of Red Meat, Poultry and Eggs (pp. 101-122). Cambridge, UK: Woodhead Publishing http://dx.doi.org/10.1533/9781845692513.101

George-Evins, C. D., Unruh, J. A., Marsden, J. L., \& Kastner, C. L. (2000). A survey of the use of blade tenderizers by beef fabrication plants. Kansas State University, Agriculture Experiment Station and Cooperative Extension Service. Retrieved from http://krex.k-state.edu/dspace/bitstream/handle/2097/4686/cattle00pg119-120.pdf?sequence=1

Gibson, H., Taylor, J. H., Hall, K. E., \& Holah, J. T. (1999). Effectiveness of cleaning techniques used in the food industry in terms of the removal of bacterial biofilms. Journal of Applied Microbiology, 87, 41-48. http://dx.doi.org/10.1046/j.1365-2672.1999.00790.x

Gill, A. O., \& Gill, C. O. (2010). Packaging and the shelf life of fresh red and poultry meats. In L. G. Robertson (Ed.), Food Packaging and Shelf Life (pp. 259-277). Boca Raton, FL: CRC Press http://dx.doi.org/10.1201/9781420078459-c14

Gill, C. O., Jones, T., Rahn, K., Campbell, S., LeBlanc, D. I., Holley, R. A., \& Stark, R. (2002). Temperatures and 
ages of boxed beef packed and distributed in Canada. Meat Science, 60, 401-410. http://dx.doi.org/10.1016/S0309-1740(01)00151-6

Ho, C. P., Huang, N. Y., \& Chen, B. J. (2004). A survey of microbial contamination of food contact surfaces at broiler slaughter plants in Taiwan. Journal of Food Protection, 12, 2809-2811.

Holah, J. T., Bird, J., \& Hall, K. E. (2004). The microbial ecology of high-risk, chilled food factories; evidence for persistent Listeria spp. and Escherichia coli strains. Journal of Applied Microbiology, 97, 68-77. http://dx.doi.org/10.1111/j.1365-2672.2004.02272.x

Holah, J. T., Taylor, J. H., Dawson, D. J., \& Hall, K. E. (2002). Biocide use in the food industry and the disinfectant resistance of Listeriamonocytogenes and Escherichiacoli. Journal of Applied Microbiology, 92, 111 S-120 S. http://dx.doi.org/10.1046/j.1365-2672.92.5s1.18.x

Huang, L., \& Sheen, S. (2011). Quantitative analysis of vertical translocation and lateral cross-contamination of Escherichia coli O157:H7 during mechanical tenderization of beef. Journal of Food Safety, 31, 108-114. http://dx.doi.org/10.1111/j.1745-4565.2010.00273.x

Johns, D. F., Bratcher, C. L., Kerth, C. R., \& McCaskey, T. (2011). Translocation of surface-inoculated Escherichia coli into whole muscle non-intact beef striploins following blade tenderization. Journal of Food Protection, 74, 1334-1337.http://dx.doi.org/10.4315/0362-028x.jfp-10-444

Keener, I. (2005). Improving cleaning-out-of-place (COP). In H. L. M. Lelieveld, M. A. Mostert, \& J. Holah (Eds.), Handbook of Hygiene Control in the Food Industry (pp. 445-467). Cambridge, UK: Woodhead Publishing http://dx.doi.org/10.1533/9781845690533.3.445

Khamisse, E., Frimesse, O., Christieans, S., Chassaing, D., \& Carpentier, B. (2012). Impact of cleaning and disinfection on the non-culturable and culturable bacterial loads of food-contact surfaces at a beef processing

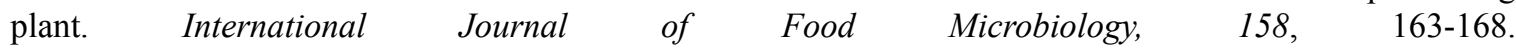
http://dx.doi.org/10.1016/j.ijfoodmicro.2012.07.014

Kusumaningrum, H. D., Riboldi, G. Hazeleger, W. C., \& Beumer, R. R. (2003). Survival of foodborne pathogens on stainless steel surfaces and cross contamination of foods. International Journal of Food Microbiology, 85, 227-236. http://dx.doi.org/10.1016/S0168-1605(02)00540-8

Laine, E. S., Schejtel, J. M., Boxrud, D. J., Vought, K. J., Danila, R. N., Elfering, T. M., \& Smith, K. E. (2005). Outbreak of Escherichia coli O157:H7 infections associated with nonintact blade-tenderized frozen steaks sold by door-to-door vendors. Journal of Food Protection, 68, 1198-1202.

Lewis, R. J., Corriveau, A., \& Usborne, W. R. (2013). Independent review of XL Foods Inc. beef recall 2012. Retrieved from http://www.foodsafety.gc.ca/english/xl_reprt-rapprte.asp

Luchansky, J. B., Phebus, R. K., Thippareddi, H., \& Call, J. E. (2008). Translocation of surface-inoculated Escherichia coli $\mathrm{O} 157: \mathrm{H} 7$ into beef subprimals following blade tenderization. Journal of Food Protection, 71, 2190-2197.

Møretrø, T., Heir, E., Mo, K. R., Habimana, O., Abdelgani, A., \& Langsrud, S. (2010). Factors affecting survival of shigatoxin-producing Escherichia coli on abiotic surfaces. InternationalJournal of Food Microbiology, 138, 71-77. http://dx.doi.org/10.1016/j.ijfoodmicro.2010.01.002

Pandey, A., Joshi, V. K., Nigam, P., \& Soccol, C. R. (1999). Enterobacteriaceae, coliforms and E. coli. In R. K. Robinson, C. A. Batt, \& P. D. Patel (Eds.), Encyclopedia of Food Microbiology (Vol. 1, pp. 604-610). Oxford: Elsevier. http://dx.doi.org/10.1006/rwfm.1999.0510

Public Health Agency of Canada, PHAC. (2013). Estimates of food-borne illness in Canada. Retrieved from http://www.phac-aspc.gc.ca/efwd-emoha/efbi-emoha-eng.php

Roels, T. H., Frazak, P. A., Kazmierczak, J. J., Mackenzie, W. R., Proctor, M. E., Kurzynski, T. A., \& Davis, J. P. (1997). Incomplete sanitation of a meat grinder and ingestion of raw ground beef: contributing factors to a large outbreak of Salmonella Typhimurium infection. Epidemiology and Infection, 119, 127-134. http://dx.doi.org/10.1017/S0950268897007851

US Department of Agriculture of Agriculture, Food Safety and Inspection Service [USDA/FSIS]. (2002). Comparative risk assessment for intact (non-tenderized) beef. US Department of Agriculture: Food Safety and Inspection Service, Technical Report. Retrieved from http://www.fsis.usda.gov/wps/wcm/connect/74ebd7c2-6af2-46f2-ba20-fec1d10d4689/Beef_Risk_Assess_R eport_Mar2002.pdf?MOD=AJPERES 
USDA/FSIS. (2012). Descriptive designation for needle or blade tenderized (mechanically tenderized) beef products. US Department of Agriculture, Food Safety and Inspection Service Guideline. Retrieved from http://www.fsis.usda.gov/wps/wcm/connect/41102961-2901-4c10-86b8-081772ad3fc0/2008-0017.htm?MO $\mathrm{D}=\mathrm{AJPERES}$

van Hoek, A. H. A. M., de Jonge, R., van Overbeek, W. M., Bouw, E., Pielaat, A., Smid, J. H., ... Heres, L. (2012). A quantitative approach towards a better understanding of the dynamics of Salmonella spp. in a pork slaughter-line. International Journal of Food Microbiology, 153, 45-52. http://dx.doi.org/10.1016/j.ijfoodmicro.2011.10.013

Youssef, M. K., Badoni, M., Yang, X., \& Gill, C. O. (2013). Sources of Escherichia coli deposited on beef during breaking of carcasses carrying few E. coli at two packing plants. Food Control, 31, 166-171. http://dx.doi.org/10.1016/j.foodcont.2012.09.045

\section{Copyrights}

Copyright for this article is retained by the author(s), with first publication rights granted to the journal.

This is an open-access article distributed under the terms and conditions of the Creative Commons Attribution license (http://creativecommons.org/licenses/by/3.0/). 